NEW DIRECTIONS IN ECONOMIC AND SOCIAL HISTORY 


\section{New Directions in Economic and Social History}

Edited by

Anne Digby

and

Charles Feinstein

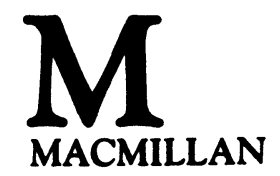




\section{(C) ReFRESH 1989}

All rights reserved. No reproduction, copy or transmission of this publication may be made without written permission.

No paragraph of this publication may be reproduced, copied or transmitted save with written permission or in accordance with the provisions of the Copyright, Designs and Patents Act 1988, or under the terms of any licence permitting limited copying issued by the Copyright Licensing Agency, 90 Tottenham Court Road, London W1P 9HE.

Any person who does any unauthorised act in relation to this publication may be liable to criminal prosecution and civil claims for damages.

First published 1989 by

\section{THE MACMILLAN PRESS LTD}

Houndmills, Basingstoke, Hampshire RG21 2XS

and London

Companies and representatives

throughout the world

ISBN 978-0-333-49569-8 ISBN 978-1-349-20315-4 (eBook)

DOI 10.1007/978-1-349-20315-4

A catalogue record for this book is available from the British Library.

Reprinted 1994 


\section{Contents}

Figures vii

Illustrations viii

Tables ix

Maps $\quad$ ix

Introduction A.Digby, C.H. Feinstein 1

I AGRICULTURE

1 Agricultural Revolution? England, 15401850 M. Overton 9

2 Parliamentary Enclosures: Gains and Costs M. E. Turner 22

3 The Highland Clearances T. M. Devine 35

II ECONOMY

4 Domesday Book after 900 Years S. Harvey 51

5 The Industrial Revolution: Economic Growth in Britain, 1700-1860 N.F.R. Crafts 64

6 British Imperialism: a Review and a Revision A. G. Hopkins 76

7 The Rise and Fall of the Managed Economy R. Middleton

\section{SOCIETY}

8 Population Growth: England, 1680-1820 E.A. Wrigley

9 Standards of Living and Industrialisation R. Floud

10 Women and Society: Continuity and Change since 1870 J. Lewis 
11 The British Welfare State: its Origins and Character P. Thane

IV LABOUR

12 Chartism E. Royle

13 The Labour Aristocracy in the British Class Structure R.J. Morris

14 Social Control in Modern Britain F. M.L. Thompson 


\section{Figures}

1 Chronology of parliamentary enclosure in England, 1750-1819

2 The tax assessment-manorial annual value relationship for Essex lay-manors, 1086

3 Inflation, unemployment and the balance of payments, 1950-85

4 Crude birth and death rates, 1681-1821

5 Expectation of life at birth and the gross reproduction rate, $1681-1821$

6 Class differences in height in the early nineteenth century, and a comparison with males in Britain today

7 Average heights of males recruited to the army at the age of eighteen, 1750 onwards

8 Changes in fertility, 1860s to 1970 s

9 Height of children as shortfall from the average at Broughton School in Edinburgh, 1904

10 Distribution of fathers-in-law, Edinburgh, 1865-9 177

11 Distribution of the occupation of fathers-in-law in Kentish London, 1851-75 


\section{Illustrations}

1 A dwelling in Skye, 1853

2 Questions asked in the Domesday Inquiry 61

3 The white elephant 84

4 How Lord Salisbury is worked 85

5 A suffragette view of women's votes 140

6 Political capital extracted from the National Insurance Act, $1911 \quad 148$

7 Welfare and Electoral Advantage: the Old Age Pensions Act, $1908 \quad 149$

8 An initially favourable view of the Charter, $1848 \quad 166$

9 A later mocking interpretation of the Charter, 1848

10 Priorities in elementary education 185

11 Impressions of a London beershop 190

12 Temperance refreshment: the Coffee Room at Dorking

13 Teaching temperance 193 


\section{Tables}

1 Estimates of wheat yields, 1520-1851 15

2 Statistics of English parliamentary enclosures 24

3 Crop distributions, productivity, and grain output in Northamptonshire, circa 1801

4 Growth rates of real output, 1700-1860 66

5 Investment as a percentage of national income, $1700-1860$

6 Sources of economic growth, 1700-1860

7 A comparison of British and European changes in economic structure, $1700-1840$

8 Growth of population in England during the 'long' eighteenth century

9 Socio-economic differences in average height in the 1880 s and today

10 Female participation in the labour force in Great Britain, 1861-1981

\section{Maps}

1 Ratio of agricultural labourers to farmers who did not employ labour, 1831

2 Density of parliamentary enclosure in England

3 Scotland: showing place names in the text

4 The growth of the British empire 